University of Nebraska - Lincoln

DigitalCommons@University of Nebraska - Lincoln

May 1991

\title{
NOVEL METHODS FOR DEPOSITION OF BORON CARBIDE FILMS
}

\author{
J. Mazurowski \\ Syracuse University \\ S. Baral-Tosh \\ Syracuse University \\ G. Ramseyer \\ General Electric Co. \\ J.T. Spencer \\ Syracuse University \\ Yoon-Gi Kim \\ Syracuse University
}

See next page for additional authors

Follow this and additional works at: https://digitalcommons.unl.edu/physicsdowben

Part of the Physics Commons

Mazurowski, J.; Baral-Tosh, S.; Ramseyer, G.; Spencer, J.T.; Kim, Yoon-Gi; and Dowben, Peter A., "NOVEL METHODS FOR DEPOSITION OF BORON CARBIDE FILMS" (1991). Peter Dowben Publications. 152. https://digitalcommons.unl.edu/physicsdowben/152

This Article is brought to you for free and open access by the Research Papers in Physics and Astronomy at DigitalCommons@University of Nebraska - Lincoln. It has been accepted for inclusion in Peter Dowben Publications by an authorized administrator of DigitalCommons@University of Nebraska - Lincoln. 


\section{Authors}

J. Mazurowski, S. Baral-Tosh, G. Ramseyer, J.T. Spencer, Yoon-Gi Kim, and Peter A. Dowben 


\section{NOVEL METHODS FOR DEPOSITION OF BORON CARBIDE FILMS}

J. MAZUROWSKIa'b, S. BARAL-TOSHa, G. RAMSEYERb, J.T. SPENCERc, YOON-GI KIMa, AND P.A. DOWBENa

a) Department of Physics, Syracuse University, Syracuse, New York 13244-1130

b) General Electric Co., Electronics Laboratory, Electronics Park, Syracuse, New York, 13221

c) Department of Chemistry, Syracuse University, Syracuse, New York $13244-4100$

\section{ABSTRACT}

By combining pentaborane $\left(\mathrm{B}_{5} \mathrm{H}_{9}\right)$ and decarborane $\left(\mathrm{B}_{10} \mathrm{H}_{14}\right)$ with methane in a plasma reactor, a variety of boron-carbides can be made over a wide range of compositions. The resulting thin films have uniform composition and appear to be polycrystalline.

\section{INTRODUCTION}

Boron carbides are of considerable interest because of their potential semiconductor properties $[1,2]$ and because these materials are very hard, chemically inert and retain a high modulus of elasticity [3]. Boron carbides have applications as neutron absorbent materials [4-8], wear resistant hard coatings, and armor coatings $[3,9,10]$. There are a number of unusual boron containing films with hardness values comparable to diamond $[9,10,11]$.

Until now boron carbides fabricated via chemical vapor deposition typically employ $\mathrm{BCl}_{3}$ reacted with a hydrocarbon (typically methane) [12-16] though variations of this approach using $\mathrm{BCl}_{3}+\mathrm{CCl}_{4}[17,18]$ or $\mathrm{BBr}_{3}[19-21]$ have been employed. We have demonstrated that decarborane is a suitable boron source material for the fabrication of boron and boron nitride coating $[22,23]$ and we now demonstrate that a wide range of boron carbide stochiometries can be fabricated by combining boranes and methane in an rf plasma reactor.

\section{EXPERIMENTAL}

Decarborane (14), $\mathrm{B}_{10} \mathrm{H}_{14}$, is an airstable white crystalline solid with a vapor pressure of several Torr at room temperature. The vapor pressure was increased for these experiments by heating (the vapor pressure at $100^{\circ} \mathrm{C}$ is 19 Torr), since the decarborane (14) decomposes only above $170^{\circ} \mathrm{C}$ [24]. The pentaborane (9), $\mathrm{B}_{5} \mathrm{H}_{9}$, with a vapor pressure of 209 Torr at $25^{\circ} \mathrm{C}$, was a vapor under the operating conditions of our experiment. 
The radio-frequency plasma deposition studies were carried out in a small 3 -inch $13.56 \mathrm{mHz}$ if plasma reactor with a 1-inch plate separation. The typical If power output of the reactor was $20 \mathrm{~W}$, but could be increased to $100 \mathrm{~W}$. The sample substrates (quartz glass or silicon) were mounted on the ground plate of the two plate system, with the other plate connected to the if network. The system used a commercial of generator and impedance matcher. Methane was used as the carbon source and no carrier gas was used.

Film composition was determined by Auger electron spectroscopy calibrated with $\mathrm{B}_{4} \mathrm{C}$ after removing surface impurities resulting from exposure to air.

\section{RESULTS}

After setting up a stable gas mixture of the gaseous borane and methane the plasma was initiated and a film was deposited. The results for decarborane and pentaborane are summarized in tables one and two.

Considering that the source gas contained no impurities, it is unsurprising that the pure films can be fabricated by this procedure as is indicated by the Auger electron spectra shown in figure one.

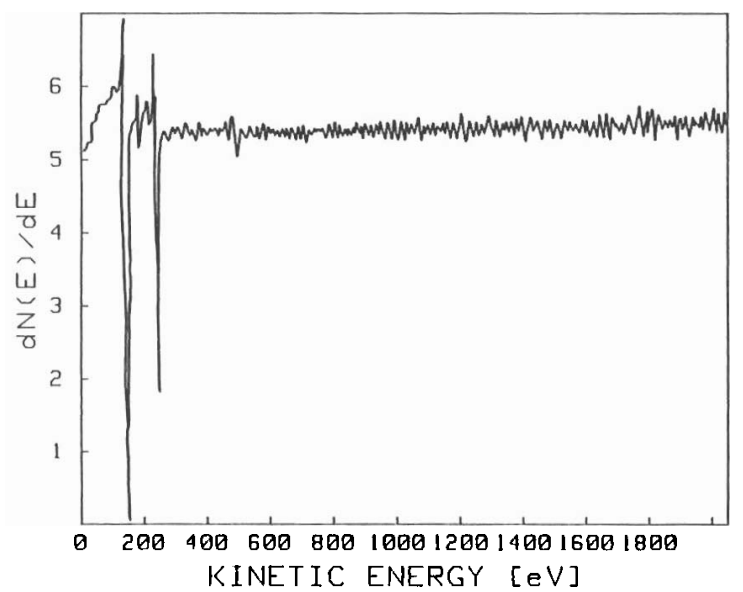

Figure 1: Auger electron spectra of boron-carbide fabricated from $44 \mu$ of $\mathrm{CH}_{4}$ and $6 \mu$ of $\mathrm{B}_{5} \mathrm{H}_{9}$ in a 20 watt if plasma.

Some oxygen incorporation was found upon exposing these films to air, particularly for the films fabricated from decaborane (14). In general the decaborane (14) films proved to be far less uniform. Decaborane (14) was far more difficult to control and vary the boron carbide film composition than pentaborane (9). 
TABLE ONE: SUMMARY OF DEPOSITIONS USING $\mathrm{B}_{10} \mathrm{H}_{14}+\mathrm{CH}_{4}$

\begin{tabular}{|c|c|c|c|c|c|c|c|c|}
\hline $\begin{array}{c}\text { Ratio } \\
\mathrm{B}_{10} \mathrm{H}_{14}: \mathrm{CH}_{4}\end{array}$ & $\begin{array}{l}\mathrm{B}_{10} \mathrm{H}_{14} \\
\text { Press } \\
\text { mTorr }\end{array}$ & $\begin{array}{l}\mathrm{CH}_{4} \\
\text { Press } \\
\text { mTorr }\end{array}$ & $\begin{array}{l}\text { Temp } \\
{ }^{\mathrm{C}}\end{array}$ & $\begin{array}{r}\text { AES } \\
\text { Comp } \\
\text { B \% }\end{array}$ & $\begin{array}{r}\text { AES } \\
\text { Comp } \\
\text { C } \%\end{array}$ & $\begin{array}{l}\text { AES } \\
\text { Comp } \\
0 \%\end{array}$ & $\begin{array}{c}\text { Thick- } \\
\text { ness } \\
\mu \mathrm{m}\end{array}$ & $\begin{array}{c}\text { Rate } \\
\mu \mathrm{m} / \\
\mathrm{min}\end{array}$ \\
\hline $4.75: 1$ & 9.5 & 2.0 & 396 & $<10$ & 50 & 50 & - & - \\
\hline $5.25: 1$ & 21.0 & 4.0 & 398 & 15 & 25 & 60 & 0.120 & 0.0027 \\
\hline $7.00: 1$ & 35.0 & 5.0 & 381 & 68 & 20 & 12 & 0.040 & 0.0012 \\
\hline $7.00: 1$ & 42.0 & 6.0 & 398 & 82 & 12 & 6 & 0.119 & 0.007 \\
\hline
\end{tabular}

TABLE TWO: SUMMARY OF DEPOSITIONS USING $\mathrm{B}_{5} \mathrm{H}_{8}+\mathrm{CH}_{4}$

\begin{tabular}{|c|c|c|c|c|c|c|c|c|}
\hline $\begin{array}{c}\text { Ratio } \\
\mathrm{B}_{5} \mathrm{H}_{9}: \mathrm{CH}_{4}\end{array}$ & $\begin{array}{l}\mathrm{B}_{5} \mathrm{H}_{9} \\
\text { Press } \\
\text { mTorr }\end{array}$ & $\begin{array}{l}\mathrm{CH}_{4} \\
\text { Press } \\
\text { mTorr }\end{array}$ & $\begin{array}{l}\text { Temp } \\
{ }^{\circ} \mathrm{C}\end{array}$ & $\begin{array}{r}\text { AES } \\
\text { Comp } \\
\text { B } \%\end{array}$ & $\begin{array}{r}\text { AES } \\
\text { Comp } \\
\text { \% }\end{array}$ & $\begin{array}{r}\text { AES } \\
\text { Comp } \\
0 \%\end{array}$ & $\begin{array}{c}\text { Thick- } \\
\text { ness } \\
\text { fmm }\end{array}$ & $\begin{array}{c}\text { Rate } \\
\mu \mathrm{m} / \\
\mathrm{min}\end{array}$ \\
\hline $1: 9$ & 5.0 & 45.0 & 449 & 68 & 28 & 4 & 0.160 & 0.0053 \\
\hline $1: 7$ & 6.3 & 43.7 & 421 & 72 & 26 & 1 & 0.290 & 0.0097 \\
\hline $1: 5$ & 8.3 & 41.7 & 426 & 78 & 20 & 1 & 0.130 & 0.0043 \\
\hline $1: 3$ & 12.5 & 37.5 & 398 & 82 & 17 & 1 & 0.044 & 0.0015 \\
\hline $1: 1$ & 25.0 & 25.0 & 414 & 90 & 8 & 2 & 0.890 & 0.0296 \\
\hline $4.9: 1$ & 41.5 & 8.5 & 443 & 94 & 3 & 3 & 0.050 & 0.0017 \\
\hline $7: 1$ & 43.7 & 6.3 & 440 & 92 & 4 & 3 & 0.400 & 0.0133 \\
\hline $9: 1$ & 45.0 & 5.0 & 439 & 93 & 3 & 2 & - & - \\
\hline
\end{tabular}


Auger electron spectroscopy, combined with $\mathrm{Ar}^{+}$ion sputtering was used to provide a depth profile of the composition. The cylindrical mirror analyzer based Auger electron spectrometer (Perkin Elmer) was calibrated using $\mathrm{B}_{4} \mathrm{C}$, from the boron $179 \mathrm{eV}$ Auger line and the carbon $272 \mathrm{eV}$ Auger line. As can be seen in figure two, the films are very uniform.

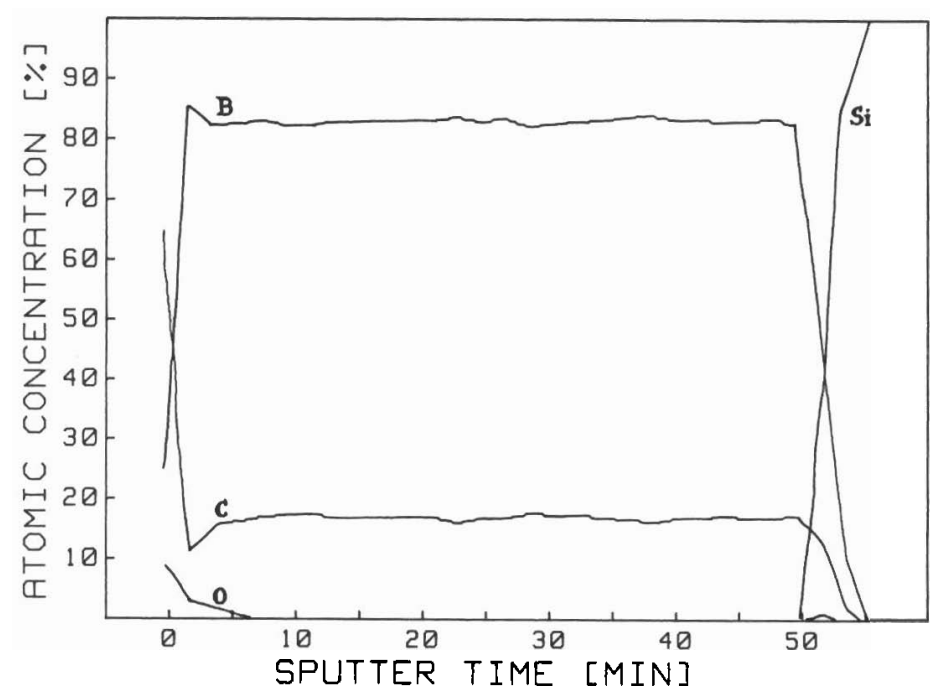

Figure 2: An Anger electron spectra depth profile of boron, carbon and oxygen of a boron carbide film fabricated from pentaborane (9) and methane deposited in a $20 \mathrm{~W}$ of plasma reactor. Percent (atomic) composition is plotted against $\mathrm{Ar}^{*}$ ion sputtering time.

\section{DISCUSSION AND CONCLUSIONS}

The composition of the boron carbide films can be correlated with reaction feed gas mixture used in the if plasma assisted process, as seen in figure three.

The film composition, even accounting for the number of boron atoms in each borane molecule (either 5 for pentaborane or 10 for decaborane), is not linearly proportional to the feed gas composition. The very rich boron films have - more carbon than expected while the less boron rich films have far more boron in the films than is expected from an inspection of the gas mixture. This suggests that a number of gaseous or surface reactions occur creating very stable intermediate carborane clusters prior to and during the film formation.

Despite the fact that film composition is not controlled simply from the gas feed mixture, films with a wide range of boron to carbon ratios can be 
fabricated. This is consistent with other chemical vapor deposition studies $[17,21]$ where boron carbides from $\mathrm{B}_{2} \mathrm{C}$ to $\mathrm{B}_{17} \mathrm{C}$ have been obtained.

While the boron-carbide films are uniform and can be made free of impurities, the films are, however, polycrystalline. The band gaps of these materials covers a wide range from about $0.8 \mathrm{eV}$ to more than $1.8 \mathrm{eV}$ as will be discussed further elsewhere. These band gaps can be correlated with the boron to carbon ratio [25]. These results and wide range of materials that can be made as outlined in this work hold great promise for these materials in applications where hard semiconductor materials can be employed such as in chemically harsh environments.

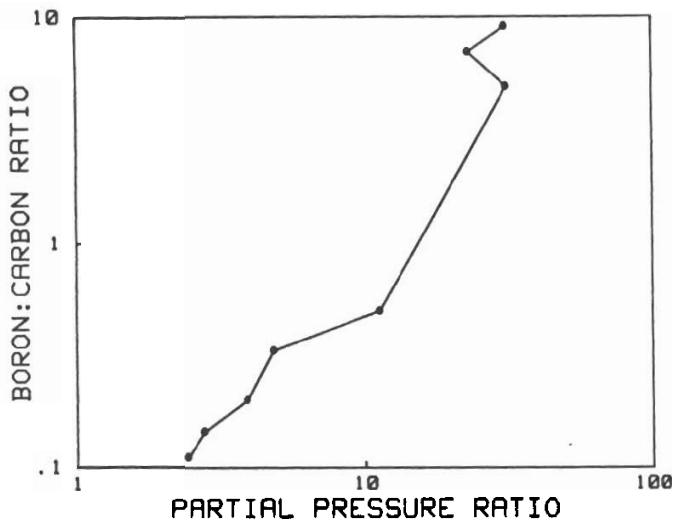

Figure 3: Boron to carbon ratios determined by Auger electron spectroscopy plotted against the ratio of pentaborane (9) to methane partial pressure.

\section{ACKNOWLEDGEMENTS}

This work was supported by I.B.M. through research agreement 9030 , the Air Force through contract no. F30602-89-C-0113, and General Electric Electronics Laboratory. 


\section{REFERENCES}

[1] D. Tomanek, R.M. Wentcovitch, S.G. Louie and M.L. Cohen, Phys. Rev. B37, 3134 (1988).

[2] C. Wood, in Boron-Rich Solids, AIP Conf. Proc. 140, 362 (1986).

[3] H.G. Budinski, Surface Engineering for Wear Resistance, Prentice Hall, New York, 1988.

[4] K.H.G. Ashbee, Acta Metall. 19, 1079 (1971).

[5] G.L. Copeland, C.K.H. DuBose, R.G. Donnelly and W.R. Martin, J. Nucl. Matter. 43, 126 (1972).

6] A. Jostons and C.K.H. DuBose, J. Nucl. Mater. 44, 91 (1972).

7 G.W. Hollenberg and W.V. Cummings, J. Am. Ceram. Soc. $\underline{63}, 376$ (1980).

8. T. Stoto, L. Zuppirolli, and J. Pelissier, Radiation Effects, 90, 161 (1985).

9] A.R. Badzian, Mat. Res. Bull. 16, 1385 (1981).

10] M. Satou, K. Yamaguch, U.S. Patent 4656052 (1987).

11. A.R. Badzian, Appl. Phys. Lett. 53, 2495 (1988).

12. U. Jansson, and J.-O. Carlsson, Thin Solid Films 124, 101 (1985).

113] M. Olsson, S. Söderberg, B. Stridh, U. Jansson, and J.-O. Carlsson, Thin Solid Films 172, 95 (1989).

[14] U. Jansson, J.-O. Carlsson, and Stridh, J. Vac. Sci. Technol. A5, 2823 (1987).

[15] L. Vandenbulcke and G. Vuillard, J. Less Common Metals 82, 49 (1981).

16] L. Vandenbulcke, R. Herbin, M. Batuscu, and J.N. Barandon, J. Less Common Metals 80, 7 (1981).

[17] D.N. Kevill, T.J. Rissmann, D. Brewe and C. Wood, J. Cryst. Growth $\underline{74}$, 210 (1986).

[18] S. Mierzejewska and T. Niemyski, J. Less Common Metals 8 , 368 (1965).

19 K. Ploog and E. Amberger, J. Less Common Metals 23, 33 (1971).

20] E. Amberger, M. Druminski, and K. Ploog, J. Less Common Metals $\underline{23}, 43$ (1971).

[21] K. Ploog, J. Less Common Metals 31, 177 (1973); J. Less Common Metals 35, 115 (1974); J. Less Common Metals 35, 131 (1974); J. Crystal Growth $\frac{25}{2} / 25,197(1974)$.

[22] Yoon-Gi Kim, P.A. Dowben, J.T. Spencer and G.O. Ramseyer, J. Vac. Sci. Technol. Aㄱ, 2796 (1989).

[23] Zhongju Zhang, Yoon-Gi Kim, P.A. Dowben and J.T. Spencer, Proc. Mat. Res. Soc. 131, 407 (1989).

[24] Callery Chemical Company, Technical Bulletin No. CM-070, 1971.

25. J. Mazurowski, G. Ramseyer, Yoon-Gi Kim and P.A. Dowben, in preparation. 